\title{
REVIEW
}

\section{Mitigation provisions to be implemented for marine seismic surveying in Latin America: a review based on fish and cetaceans}

\author{
Alberto Acosta ${ }^{1, *}$, Nelsy Niño-Rodríguez ${ }^{1}$, Maria Camila Yepes ${ }^{1}$, Oliver Boisseau ${ }^{2}$ \\ ${ }^{1}$ UNESIS, Biology Department, Faculty of Science, Pontificia Universidad Javeriana, Carrera 7 No. 40-62, Bogotá, Colombia \\ ${ }^{2}$ Marine Conservation Research International, 94 High Street, Kelvedon, Colchester CO5 9AA, UK
}

\begin{abstract}
Population growth and economic development in Latin America has led to an increase in seismic surveying to find new marine hydrocarbon reserves. However, most countries along the Pacific, Atlantic, and Caribbean lack the standards to minimize the impact of seismic exploration on marine organisms. We searched primary and secondary literature in major databases and consulted international authorities and oil companies to provide scientific evidence of the effects of seismic surveying on fish and cetaceans in order to propose minimum guidelines to reduce disturbance to marine organisms in Latin America. The results suggest that seismic surveys can disrupt basic life-cycle activities such as movement, communication, and feeding. Typical outcomes include sub-lethal effects such as escape behavior, habituation, temporary loss of hearing, and changes in vocalization behavior. In order to mitigate these impacts, we propose that oil companies must provide authorities with an environmental impact assessment that includes survey data, array specifications, and acoustic array properties before a hydrocarbon exploration license can be granted. Standard mitigation measures such as exclusion zones, marine mammal observers, and passive acoustic monitoring must be implemented to prevent potential adverse effects. Appropriate legislation and regulations must be designed and implemented, and environmental authorities should be privy to all activities by seismic vessels. Besides relevant regulations and continued monitoring, further investigation must be conducted to evaluate the impact of these activities on marine organisms. The adoption of these proposed minimum guidelines is highly recommended to minimize seismic surveying impact on fish and cetaceans in Latin American countries.
\end{abstract}

KEY WORDS: Marine seismic exploration - Fish - Cetaceans - Acoustic - Sub-lethal impacts · Risk assessment

\section{INTRODUCTION}

Approximately $31 \%$ of global energy comes from oil (International Energy Agency, www.iea.org), making it themost widely used energy source. About $10 \%$ of oil extracted worldwide is consumed by Latin America. Population growth and economic development have increased the demand for this resource and the need to find new hydrocarbon reserves on land and under the seabed. Central to the search for marine hydrocarbons

${ }^{*}$ Corresponding author: laacosta@javeriana.edu.co is seismic surveying (Speight 2015), a geophysical method to diagnose the characteristics of the seabed. Oil operators worldwide use this technique to produce subsurface maps to determine the probability of the occurrence of new oil and gas sources (Ramos et al. 2012, Kearey et al. 2013, Speight 2015).

Seismic surveys use airguns to generate impulsive signals. A specific volume of air is released under high pressure; the expansion and contraction of the released air bubble create a sound wave (Hawkins et

(C) The authors 2017. Open Access under Creative Commons by Attribution Licence. Use, distribution and reproduction are unrestricted. Authors and original publication must be credited. 
al. 2015). This is the acoustic signal used to survey the substrate. The frequency, amplitude, intensity, particle motion, and duration (i.e. impulse) are key properties of a seismic signal that determine any impact on marine life. The primary pulse generated by a seismic source is omnidirectional and short-lived; it has a rapid rise time followed by a period of energy decay (Urick 1983, Hawkins et al. 2015). For a single airgun, peak energy is below $200 \mathrm{~Hz}$ on average. Although most energy for an array of airguns is between 10 and $200 \mathrm{~Hz}$, it may extend to over $2200 \mathrm{~Hz}$ (Goold \& Fish 1998). The total acoustic energy of a pulse generated by a single airgun or an array can be measured as the sound exposure level (SEL) in conjunction with other metrics such as rise time, peak amplitude, and crest factor. When multiple signals occur, the cumulative sound exposure level ( $\left.\mathrm{SEL}_{\text {cum }}\right)$ can be calculated by adding the SEL measurements for the total period (days, months) to which an animal is exposed (Hastings \& Popper 2005, Popper \& Hastings 2009). The sound pressure level (SPL) is a logarithmic measure of the pressure of a sound relative to a reference value (1 $\mu \mathrm{Pa}$ ) and is measured in decibels $(\mathrm{dB})$ (Supin et al. 2016). The peak SPLs of individual airguns are as high as $230 \mathrm{~dB}$ re $1 \mu \mathrm{Pa}$ back-calculated to a range of $1 \mathrm{~m}$ from the source (Popper et al. 2005). To produce higher intensities, multiple airguns are fired with precise timing to generate a coherent pulse of sound; broadband levels of 248 to $255 \mathrm{~dB}$ re $1 \mu \mathrm{Pa}$ are typical of a full-scale array for receivers $>1 \mathrm{~km}$ directly underneath the source (Richardson et al. 1995). The peak spectral level for airgun arrays lies in the 5 to $300 \mathrm{~Hz}$ range (Hildebrand 2009). The airguns are fired at regular intervals (e.g. every 10 to $15 \mathrm{~s}$ ) as the towing vessel moves forward; a survey may continue in the focal area for hours, days, or months (Richardson et al. 1995, Hawkins et al. 2015). The duration of the discharge is determined by the purpose and range required by the oil operator in the area being explored (Serway \& Jewett 2013). This process is usually uninterrupted because of the high operating costs and rental of special vessels equipped with seismic cable, air guns, hydrophones, and other technology required to carry out this activity (Ebuna et al. 2013, Xia et al. 2015).

Oceanographic characteristics make sound propagation different in each region (i.e. subtropical vs. tropical). Similarly, seabed properties and bathymetry can reduce or increase the range of a sound wave (transmission from source to receiver) and alter its effects. Although several sound propagation models have been developed and described, they depend on the oceanographic characteristics. Models designed for deep waters will not be applicable in shallow-water environments where the wavelength of the sounds may be close to the depth of the water (Hovem et al. 2012). A description of oceanographic and geo-acoustic properties, as well as characterization of the disturbance in the area to be explored, should be required.

The effects of seismic surveying on an animal depend on its exposure to the sound, the number of events, the magnitude of individual signals, and the time between signals; an animal's behavior and movement in relation to the source is also influential (Popper et al. 2014). Some invertebrates, fish, cetaceans, and other marine mammals have morphophysiological adaptations that allow them to detect and interpret sounds underwater (Hawkins \& Rasmussen 1978, Gannon et al. 2005, Ward et al. 2011). They use sounds to perceive their environment, communicate, find shelter and food, and avoid predators (Kenyon et al. 1998, Amorim \& Neves 2007, Aalbers \& Drawbridge 2008, Holt \& Johnston 2011).

Marine species vary in their potential susceptibility to harm from underwater sound. Hearing loss in fish and cetaceans can be temporary or permanent. Temporary threshold shift (TTS) is a temporary reduction in hearing sensitivity caused by exposure to intense sound, influenced by the duration and magnitude of the sound (Finneran et al. 2001, Hastings \& Popper 2005). Permanent threshold shift (PTS) is harm to the sensory hair cells in the ear, the innervating auditory nerve fibers, or to other tissues in the auditory pathway such as the swim bladder (Hastings \& Popper 2005, Liberman 2016). Most marine bony fish have a swim bladder, which is a hydrostatic air cavity that enables the fish to maintain buoyancy (Evans et al. 2014). The air-tissue interface of the bladder functions as a powerful acoustic resonator (Hastings \& Popper 2005, Ladich \& Fay 2013), making fish with this interface more susceptible to pressure-mediated injury (sound pressure and barotrauma) than species without it (Stephenson et al. 2010, Carlson 2012). In many countries, however, basic information on marine animals, including life history and behavioral responses, are neither recorded nor made public.

Since the 1980s, several campaigns have been launched in Latin America to promote foreign investment in seismic surveying to identify oil and hydrocarbon sources in the seabed. In Colombia, the National Hydrocarbons Agency (ANH) manages this resource. This agency auctions marine zones or blocks in the Caribbean and Pacific to oil companies worldwide. Among the companies scanning the seabed are Petrobras (Brazil), Anadarko (United States), Ecopetrol (Colombia), ONGC Videsh (India), Repsol 
(Spain) and Shell (Anglo-Dutch). According to the $\mathrm{ANH}_{\text {, in }} 2016$ there were 12 marine areas under exploration; 11 blocks in the Caribbean and 1 in the Pacific. These numbers represent approximately 34 million ha or $10 \%$ of the Colombian seascape, which is a significant portion of the territory. Increasing energy demands will intensify the use of seismic surveying as in many other Latin American countries. Marine creatures in Colombia will potentially be exposed to these activities; therefore, appropriate mitigation standards must be implemented and adapted.

In Latin America, only Brazil has its own guidelines and marine seismic regulations. Argentina and Colombia have designed guidelines based on those implemented in the UK and USA (Reyes et al. 2016). Eleven countries require oil companies to submit environmental impact assessments (EIAs) prior to granting licenses (Reyes et al. 2016). That leaves more than 15 countries along the Pacific, Atlantic, and Caribbean lacking the requirements or standards to minimize the impacts of seismic exploration. There is an urgency in Latin America to design, propose, and standardize comprehensive guidelines that can be shared by all countries, and to assemble information on the different regions to understand the scale of the impact. The objective of this manuscript was to propose a set of guidelines to reduce disturbances and to recommend other mitigation actions. To this end, we reviewed the literature to compare and select the most accepted international regulations. To support the guidelines formulated, we also examined the scientific evidence on the effects of intense impulsive sounds on fish and cetaceans. This manuscript underscores vital issues that oil companies must address from the outset, such as requesting a license to conduct a seismic survey, measuring the environmental impact, and implementing mitigation provisions during the seismic survey. This scientific and technical information will support environmental authorities in Latin America and developing countries in the formulation of laws and regulations to produce concerted control protocols and precautionary mitigation measures.

\section{METHODS}

Rather than provide an exhaustive body of scientific evidence, this review postulates minimum regulation and mitigation protocols based on general trends apparent in the literature on the impacts of seismic activities on fish and cetaceans. For this, we searched primary and secondary literature in major databases such as ISI Web of Science, Scopus, ASFA, Science Direct, Annual Reviews, Google Academics, Latindex, Redalyc, Scielo, and publishers such as Springer and Elsevier, among others. We used the keywords 'seismic surveying, marine mammals, fish, environmental, air guns, seismic oil exploration, echolocation, fish hearing, masking sounds, hearing cetaceans, offshore seismic, sound, hearing and seismic vessels' in both English and Spanish. We filtered the information published in reviews, original articles, short communications, and literature in press from the last 4 decades that demonstrated effects and no effects. The scientific articles were selected based on the quality of evidence and scientific rigor (e.g. experimental data, soundness of their results and conclusions). We excluded articles that failed to report the frequencies, intensities, or sound levels of the seismic signals, as well as descriptive studies with limited results or overly speculative discussions. Articles on fish and cetaceans that met the criteria described above were synthesized in an Excel spreadsheet to identify sublethal or lethal effects of seismic surveying on these individuals. The reference list provided in this study refers only to those authors mentioned within this text and is not a full list of all reviewed papers. The objective of this work was to present general trends, and it was accepted that some subjectivity in different researchers' assessment of sub-lethal or lethal effects was inherent but unavoidable. Some limitations were identified in the data currently available, with a lack of experimental reports considering lethal effects.

To define minimum regulation and mitigation protocols to reduce disturbance to marine organisms during seismic surveying (based on sub-lethal and no-evidence reports), we used 6 well-known and frequently revised regulations from the USA, Canada, Mexico, New Zealand, Australia, and the UK, some of which have already been adopted in certain Latin American countries. We also consulted local (Ministry of Environment of Colombia, Housing and Territorial Development, ANH, National Environmental Licensing Authority, and the Colombian Directorate General for Maritime Policy) and international authorities, as well as oil companies (Ecopetrol, Anadarko), and a researcher in the field (Vladimir Puentes) to corroborate information, request articles (grey literature), and direct the literature search.

\section{RESULTS AND DISCUSSION}

A total of 52 experimental studies were identified documenting sub-lethal effects. (Tables $1 \& 2$ show 


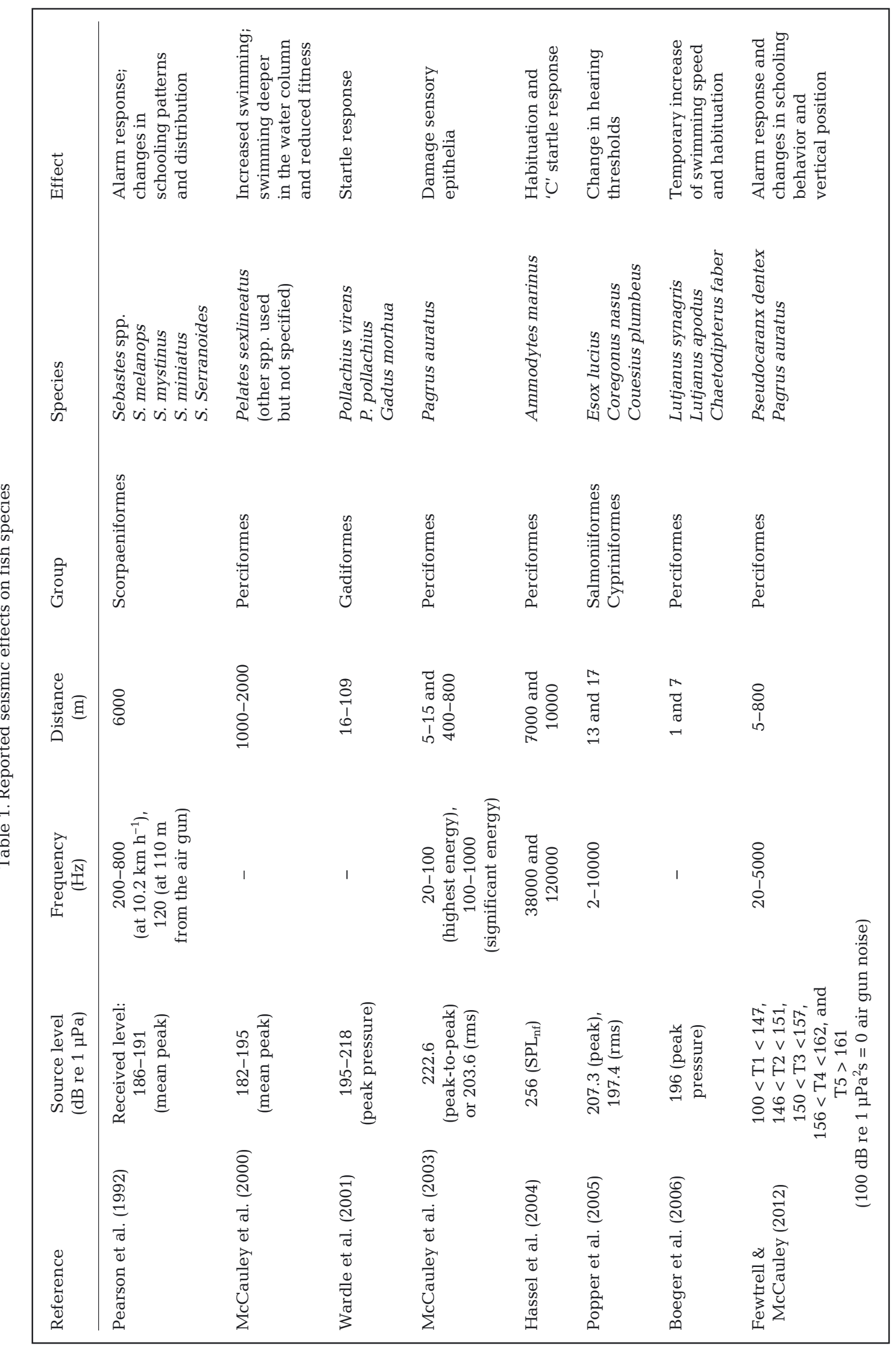




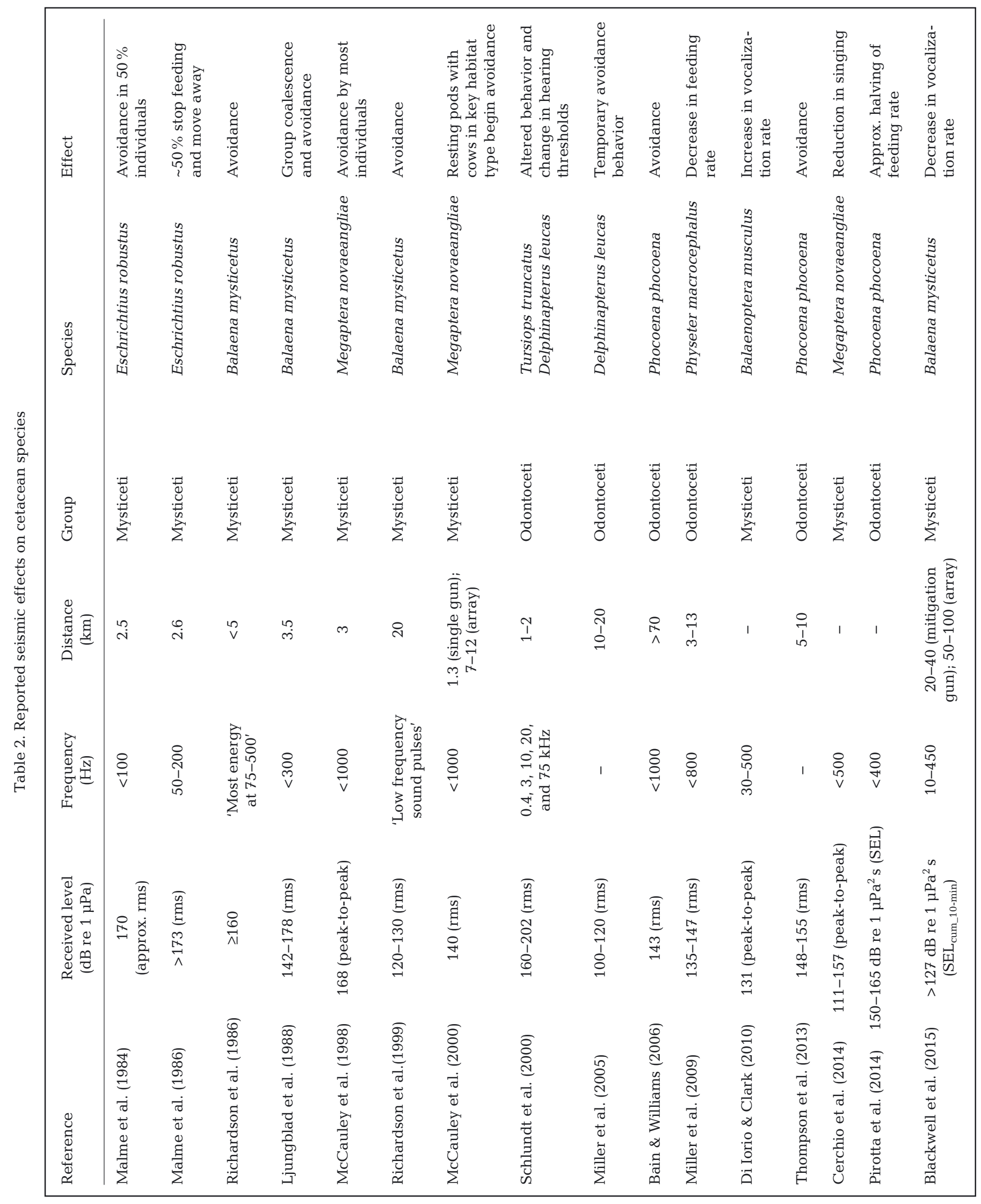


several examples of different groups that represents general behavioural trends to sound effects.) Of these articles, 25 reported on the effects of noise exposure on fish and 27 on cetaceans. Fifty percent of the papers on fish involved captive studies, whereas almost all of the articles on cetaceans involved freeranging individuals (in situ), in part due to the additional ethical and logistical considerations involved in studies of captive marine mammals.

\section{Sub-lethal effects}

The potential susceptibility of fish to being harmed by sound varies by taxa (Table 1). The signals produced by seismic surveying have been documented to cause some fish to flee (Fewtrell \& McCauley 2012), although the response to impulsive noise is reduced after repeated exposure (Radford et al. 2016). Seismic signals can elicit a startle response in coral reef fishes (Boeger et al. 2006) and a change in their swimming pattern, whereby individuals move to the bottom of the water column and swim faster in tighter groups (Pearson et al. 1992, Fewtrell \& McCauley 2012, Neo et al. 2015); the latter behavior is also called atypical mass stranding in squids (Guerra et al. 2004, 2011). Decreases in fish abundance and lower catch rates have also been reported after seismic surveys (Løkkeborg \& Soldal 1993, Engås et al. 1996, Engås \& Løkkeborg 2002, Slotte et al. 2004, Løkkeborg et al. 2012a,b). Some of these effects may be temporary in certain species, such as rockfish, occurring only during exposure to the sound (Pearson et al. 1992). Considering that seismic waves travel at $1500 \mathrm{~m} \mathrm{~s}^{-1}$ and fish easily swim at speeds of 2 to 3 body lengths $\mathrm{s}^{-1}$, trying to escape a proximal point source of noise to avoid harm is futile (Blaxter 1969, Kasumyan 2009). Little sound would be deflected by the body of a fish; most would travel straight through it, due to the similarity in density of the fish's body and the water. Nevertheless, to escape the disturbance, teleost fish activate motor neurons (Smith et al. 2003), curving their body in a ' $\mathrm{C}$ ' shape away from the noise source (startle response; Pearson et al. 1992, Santulli et al. 1999, McCauley et al. 2000, Wardle et al. 2001, Hassel et al. 2004, Boeger et al. 2006). The effects of changes in pressure (barotrauma) must also be considered for animals that attempt to flee the source of noise (Carlson 2012). In a similar manner, squid Sepioteuthis australis may move away (backwards) from the air gun; as an alarm response, they eject ink at the first air gun signal (162 dB re $1 \mu \mathrm{Pa}^{2} \mathrm{~s}$ and $174 \mathrm{~dB}$ re $1 \mu \mathrm{Pa} \mathrm{rms}$ ) and change color (McCauley et al. 2000, Fewtrell \& McCauley 2012). In some cases, the changes in swimming behavior and orientation may show signs of habituation with repeated presentations of the same sound (Popper et al. 2014). A forced habituation to disturbance has been observed in reef fish, which do not retreat from their habitat but remain in the area affected by the seismic impulses (Boeger et al. 2006, Evans et al. 2014). The potential for this behavior to generate cumulative damage to the auditory system of these fish has yet to be demonstrated.

There are substantial differences in the effects of airguns on the behavior, hearing sensitivity, and thresholds of different fish species (Popper et al. 2005, 2014). Popper et al. (2014) suggest TTS may occur at $>186 \mathrm{~dB} \mathrm{SEL}_{\text {cum }}$ for fish with no swim bladder using particle motion detection, and $<186 \mathrm{~dB}$ $\mathrm{SEL}_{\text {cum }}$ for fish with a swim bladder involved in hearing. TTS resulting from temporary changes in sensory hair cells of the inner ear and damage to auditory nerves innervating the ear have been reported in some fish (Liberman 2016). According to Hastings \& Popper (2005), unlike in the auditory receptors of mammals, sensory hair cells in fish are constantly generated and replaced when damaged; this regeneration enables the restoration of hearing. McCauley et al. (2003) found significant damage to the sensory epithelia of pink snappers Pagrus auratus, apparent as ablated hair cells, which resulted in mechanical damage to the tissue. Caged snappers were exposed to signals from an airgun towed toward and away from the cages, mimicking the stimulus from a passing seismic vessel; the airgun was towed from startup at 400 to $800 \mathrm{~m}$ away to 5 to $15 \mathrm{~m}$ at the closest range to the cage. Popper et al. (2005) found that exposure over several hours to multiple airgun shots produced damage to the sensory epithelia of the saccule, the major auditory end organ of the fish ear; there was no evidence of replacement of damaged sensory cells up to $58 \mathrm{~d}$ post-exposure. Acoustic trauma in sensory hair cells has also been reported in the statocysts of cephalopods (André et al. 2011, Guerra et al. 2011). However, behaviors such as avoidance responses to intense sound levels are probable in nature, and no harm may also be a possible outcome. PTS has not been reported. Noticeably, these aspects should be studied further to minimize the potential impact on marine life in the region and to define mitigation zones in the regulatory guidelines of seismic prospecting activities (see Tables $3 \& 4$ ).

Physiological responses have also been reported in fish; however, they are scarce and mostly conducted in laboratory settings. Respiration and oxygen con- 
sumption rates have been used as measures of direct physiological response in fish (Radford et al. 2016), cephalopods (Kaifu et al. 2007), and lobsters (Filiciotto et al. 2014). As an example, European seabass exposed to playbacks of recordings of pile-driving and seismic surveys exhibited increased ventilation rates in relation to control individuals exposed to ambient-noise playback (Radford et al. 2016). Meanwhile, adrenaline and cortisol rates (Sverdrup et al. 1994, Santulli et al. 1999), heat shock proteins, as well as immune responses have been used as indirect measures of physiological response; these responses may lead to an energy trade-off and thus influence survival and reproduction.

In cetaceans, experiments studying behavioral responses of captive or caged animals reported significantly increased mean levels of 3 stress hormones immediately after a high exposure to the impulsive noise produced by a seismic water gun; this was inconsistent in the case of a captive beluga whale subjected to low-level exposure (Romano et al. 2004). The responses of free-ranging animals may be different because of the many variables that determine an animal's behavior in a natural setting. According to Wartzok et al. (2003), behavioral responses in mammals vary according to age, gender, condition, behavioral state, and context (environmental conditions). Because of the ethical considerations and high costs involved, empirical studies involving the controlled exposure of free-ranging individuals to airgun noise are rare. In a recent example, the soft start of a small experimental airgun array off Australia caused humpback whale groups to slow down and deviate from their course, indicating a potential avoidance response (Dunlop et al. 2015).

Disorientation or erratic movements in cetaceans may affect vital functions such as reproduction and sexual selection, and the efficient search for food (Allen 2015). Disorientation and changes in swimming patterns are among the behavioral changes observed in both fish and cetaceans (Tables 1 \& 2; Pearson et al. 1992, Aguilera-Hellweg \& McCarthy 2002, Jepson et al. 2003, McCauley et al. 2003, Popper 2003, Hildebrand 2004, Slotte et al. 2004, Stone \& Tasker 2006, Nowacek et al. 2007, Truett 2007, Weilgart 2007, Cerchio et al. 2014, Allen 2015).

Other responses documented for cetaceans include alteration of movements and dive profiles, abandonment of habitat (temporary or permanent), changes in vocalization type/rate, and interruption of feeding and social behavior (Richardson et al. 1995, McCauley et al. 2000, Evans \& England 2001, Engel et al. 2004, Scheifele et al. 2005, Cox et al. 2006,
Nowacek et al. 2007). Although no cases of habituation to seismic airguns have been observed in cetaceans, a study by Castellote et al. (2012) in regions of high shipping density reported on the vocal activity of singing fin whales in the Straits of Gibraltar, suggesting that some species may habituate to certain types of low-frequency noise. Cetaceans are more likely to become sensitized to seismic signals when a noise stimulus that could generate physiological damage is recurrently used, based on the strong reactions observed in fin whale movements at the onset of airgun activity (Castellote et al. 2012).

In cetaceans, exposure to intense sounds can cause a temporary diminishing of hearing sensitivity (Finneran et al. 2001), or influence the degree of threshold shift (defined as a $6 \mathrm{~dB}$ or higher increase in postexposure thresholds compared with pre-exposure levels; Schlundt et al. 2000, Lucke et al. 2009). The direct effects on marine mammals exposed to sound remain largely undetermined in journal articles; however, substantial evidence can be found in grey literature. A study by Wisniewska et al. (2014) conducted during 4 simultaneously occurring seismic surveys indicated that narwhals experienced, on average, an $86 \%$ reduction in hearing range at lower frequencies. Therefore, measuring and reporting the specific sound level, duration, amplitude, frequency content, energy distribution, and temporal pattern of noise exposure during seismic surveys and relating them to life cycle and population demography variables such as mortality (stranding) and reproduction (breeding) is essential. Another factor that must be explored further is the synergy with other sound disturbances (e.g. engines, sonars).

There is a range of overlap in the frequencies used in seismic prospecting and those used by cetaceans ( 7 to $180000 \mathrm{~Hz}$, depending on the species; Brkic et al. 2004, Southall et al. 2007, Nowacek et al. 2007) and fish (100 to $4000 \mathrm{~Hz}$, depending on the species; Mann et al. 2001). For example, Fig. 1 shows that the balaenopterids typically use frequencies below $10 \mathrm{kHz}$ (Southall et al. 2007, Vaughan et al. 2013). This overlap with the seismic signal (airgun arrays) may result in masking, whereby acoustic interference reduces a receiver's ability to perceive, recognize, or decode a sound of interest. The extent of interference depends on the spectral, temporal, and spatial relationship between a signal and the masking noise, among other factors. Behavioral effects in individuals have been observed as a result of this masking such as the reduced ability to locate conspecifics (Clark et al. 2009). In the case of cetaceans, McCauley et al. (2000) and Southall et al. (2007) hypothesized that 


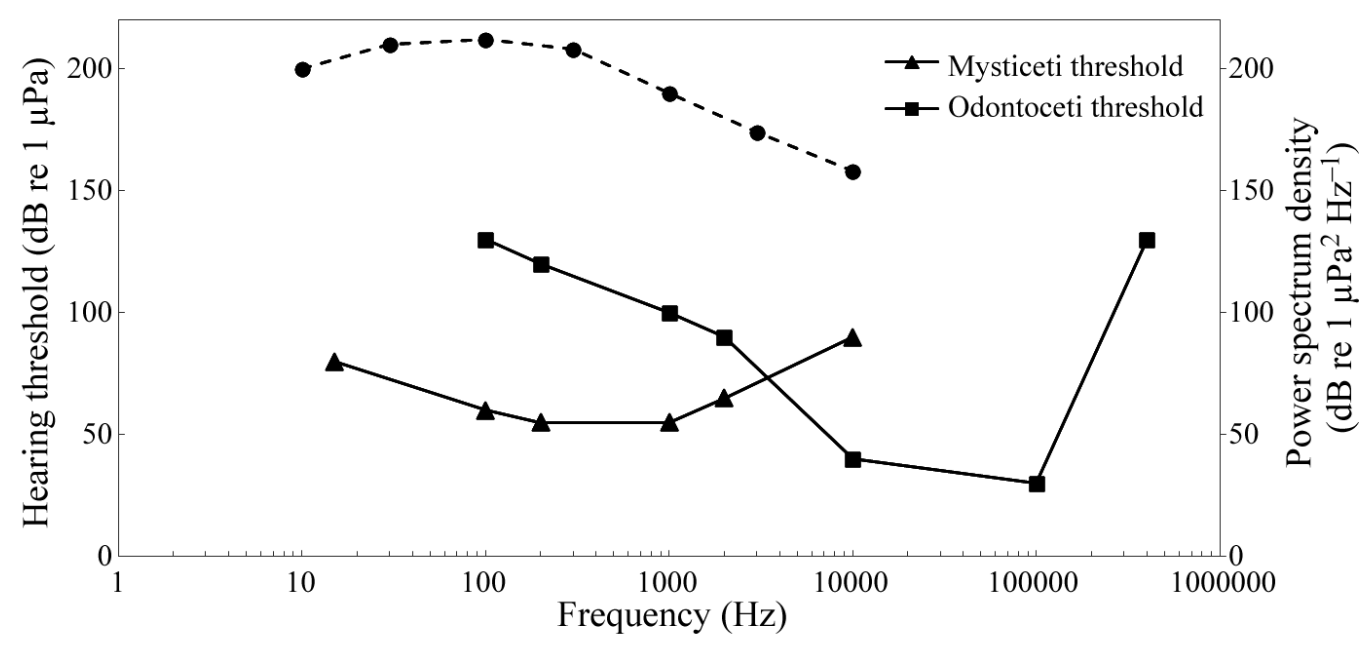

Fig. 1. Composite hearing thresholds for cetacean species modified from Southall et al. (2007) and Popper et al. (2014). A representative power spectrum of a $2900 \mathrm{in}^{3}\left(47522 \mathrm{~cm}^{3}\right)$ airgun array is plotted on the secondary axis (taken from Erbe 2011).

Dashed line represents the range used in seismic surveying

their ability to communicate with their young could be obstructed. High levels of noise may also generate changes in the song patterns of male baleen whales calling to females in breeding grounds (McCauley et al. 2000, Southall et al. 2007). The potential for acoustic masking increases when multiple airguns are fired. Biological sounds including the $20 \mathrm{~Hz}$ calls of fin whales become masked in acoustic data when multiple airguns are used simultaneously (Nieukirk et al. 2012). Clark \& Gagnon (2006) showed that fin whales stopped singing when an average of 3 and up to 5 seismic survey vessels operated simultaneously.

A seismic survey using low-level power caused blue whales to modify their vocalizations (Di Iorio \& Clark 2010), suggesting that even low source level seismic survey noise could interfere with important signals used in social interactions and feeding. It is unclear whether the energetic expenditure of continuous singing in high-noise areas may be significant or not; this should be measured. For example, the North Atlantic right whale Eubalaena glacialis broadens the amplitude of its calls in higher noise conditions (Parks et al. 2011) and increases the frequency of its calls when low-frequency noise is present (Parks et al. 2007). To maintain the signal-to-noise ratio the callers adjust their calls. However, we need to explore whether communication range is maintained, as well as the potential effects on the population.

\section{Potential lethal effects}

Noise exposure has the potential to induce direct or indirect physiological effects on non-auditory systems; this is particularly apparent in cetaceans (Southall et al. 2007). Whales typically balance dives to manage nitrogen bubble formation; a sound stimulus may disrupt the animals' normal dive regime (Houser et al. 2001). A sudden change in air pressure allows the formation of in vivo nitrogen bubbles that can migrate into the circulatory system, causing tissue damage (Southall et al. 2007). It is unclear whether this behavior is to avoid the sound source or the sound itself. Deep-diving toothed whales (e.g. Mesoplodon densirostris) may ascend abruptly to the surface in response to intense anthropogenic sonar signals, causing internal lesions such as gas and fat emboli (Jepson et al. 2003, Hildebrand 2004, Fernández et al. 2005, Nowacek et al. 2007, Dolman et al. 2008). This has also been reported in harbor porpoises Phocoena phocoena (Jepson et al. 2003), as well as Risso's Grampus griseus and common Delphinus delphis dolphins (Dennison et al. 2012). There are no conclusive results showing lethal effects of seismic surveys on cetaceans (Heide-Jørgensen et al. 2013) but based on indirect evidence, some authors argue that it could be a possible outcome (Taylor et al. 2004).

\section{No effects}

Recent experimental and observational studies found no sub-lethal response in fish regarding swimming speed, swimming direction, startle response (Cott et al. 2012, Peña et al. 2013), TTS (Hastings \& Miksis-Olds 2012), hearing capabilities (Popper et al. 2005, Song et al. 2008, McCauley \& Kent 2012), abun- 
dance or school size (Peña et al. 2013), and catch rates after seismic exposure (Hassel et al. 2004, Miller \& Cripps, 2013, Thomson et al. 2014). Similarly, no difference was documented on injuries to the kidney and swim bladder tissue of fish when comparing in situ organisms $3 \mathrm{~m}$ away from the seismic airgun array and within $34 \mathrm{~m}$ of the source (Popper et al. 2016). No hair cell loss or otolith damage has been reported regarding other anthropogenic noise sources such as a hydraulic watergun (Wagner et al. 2015).

There are other examples of no evidential effects of seismic exposure in invertebrates. Andriguetto-Filho et al. (2005) found no change in shrimp behavior from source levels near $196 \mathrm{~dB}$ re $1 \mu \mathrm{Pa}$ rms. Boudreau et al. (2009) indicated that high-level impulsive sounds have no short- or long-term effects on adult and juvenile snow crabs or their eggs. Parry \& Gason (2006) found no effect on rock lobster catch rates near offshore seismic survey areas where impacts would be expected to be minimal. No effects on catch rates have also been reported for cephalopods, bivalves, gastropods, and crabs (La Bella et al. 1996, Courtenay et al. 2009).

\section{Possible impact management}

\section{Regulations}

The Colombian Ministry of the Environment and Sustainable Development (MADS) is designing a guide to regulate marine seismic activity in that country. This guide is based on the British guidelines by the Joint Nature Conservation Committee (JNCC 2010, 2017) and uses its scope and measures. Although a noteworthy effort, adapting and making minimal changes to a guide intended for use in another country with its particular sound propagation conditions and biotic communities without prior study is inadequate, especially if the attributes and behavior of seismic signals in the waters of the tropics and the potential effects on local biota are overlooked. This inappropriate implementation of regulations also occurs in other Latin American countries. Reyes et al. (2016) reviewed legislation to address the potential impacts of seismic airgun noise in 20 Latin American countries (continental countries, Cuba, and the Dominican Republic). They found that Brazil and Peru are the only countries that enacted regulation guidelines. Despite requiring regulations based on local-regional scientific information, other countries have adopted foreign international guidelines, like Colombia using the JNCC (UK). Thus, regula- tory protocols must be site-specific. Region-specific regulations and mitigation protocols must be implemented by the relevant environmental authorities.

\section{Minimum guidelines}

We propose a list of parameters to be considered during seismic surveying in any developing country (Table 3). Oil companies should provide the government with an EIA including all proposed parameters before a hydrocarbon exploration license is granted, and after the exploration has been completed (final report). The parameters specified in Table 3 must be adopted and must consider specific local considerations regarding sound propagation conditions, seismic methods used, as well as habitats and species disturbed.

Environmental authorities should be privy, through detailed reporting, to all exercises by seismic vessels, prior to and after the planned activity (see Tables 3 \& 4 ), including information such as the source level and direction of the airgun arrays used, as well as the duration of the 'soft-start' procedure and the firing pattern planned for 'line changes' (when the seismic vessel turns at the end of one survey line prior to commencement of the next predetermined line; Kearey et al. 2013, Persen 2013). These reports should also indicate, with additional studies, whether the soft-start procedure will likely drive away marine organisms from the mitigation zone, at what intensity this happens, for how long, and which species are repelled by this procedure in the survey site. Further details should be included such as the method used to verify whether individuals moved outside of the area of impact, considering that the speed of sound in marine water is about $1500 \mathrm{~m} \mathrm{~s}^{-1}$ and average fish swimming speeds are 2 to 3 body lengths $\mathrm{s}^{-1}$ (Blaxter 1969, Kasumyan 2009). These reports should also include the type of survey, survey timing, and duration of the sound emitted during the seismic survey operation, the arrangement of the airguns and the characteristics of the sound disturbance, and the systematic in situ/in vitro quantification of sub-lethal or lethal impacts on local vertebrates, invertebrates, and zooplankton (McCauley et al. 2017) during and after the operation in the area surveyed.

In some regions, reporting is completed via an EIA form that is submitted before the approval of a seismic survey. Currently, 11 Latin American countries require EIAs, although none require in-field groundtruthing of models that include local propagation features and predicted exclusion zones. Only Argentina, 
Table 3. Proposal of minimum parameters to be considered during seismic surveying in Latin American waters. These survey parameters must be declared during the preparation of an environmental impact assessment (EIA) and after the exploration. Prior to applying for a hydrocarbon exploration license, an EIA should be prepared by the relevant company and presented to the environmental agency. A final report after the activity must include those parameters. Regulation documents from Canada, Mexico, New Zealand, Australia, and the UK were used to build these proposals (Australian Government 2008, Canada National Energy Board 2008, JNCC 2010, 2017, New Zealand Department of Conservation 2013, Minerals Management Service Gulf of Mexico OCS 2016). PAM: passive acoustic monitoring; SEL: sound exposure level

\begin{tabular}{|c|c|}
\hline Survey parameters & Notes \\
\hline \multicolumn{2}{|l|}{ Survey data } \\
\hline Type of survey & 2D, 3D, well-testing, etc. \\
\hline Map of the survey area & Including all survey lines \\
\hline Survey timing & Start and end dates of survey \\
\hline Duration & Expected length of survey \\
\hline Duty cycle & Hours of firing per $24 \mathrm{~h}$ \\
\hline Night operations & Hours of firing in the dark per $24 \mathrm{~h}$ \\
\hline Number of vessels & Number and type of accompanying vessels \\
\hline \multicolumn{2}{|l|}{ Array specifications } \\
\hline Vessels towing airguns & Number and names of vessels \\
\hline Geometric layout of array & Including individual airgun volumes used by each vessel \\
\hline Size of total array & Cubic inches and PSI for the entire array \\
\hline Firing rate & Shots $\mathrm{s}^{-1}$ \\
\hline Firing pattern & Sub-arrays firing simultaneously or alternately \\
\hline Operation speed & Likely speed of vessel \\
\hline \multicolumn{2}{|l|}{ Acoustic properties of the array } \\
\hline Far-field pressure signature & Figure required \\
\hline Far-field particle velocity (or acceleration) & In $x$ and $y$ directions. For further details check Amundsen et al. (2016) \\
\hline Far-field frequency spectrum & Figure required (broadband) \\
\hline Source level of array on axis & $\begin{array}{l}\text { Given in all of the following units: } \\
\mathrm{dB} \text { re } 1 \mu \mathrm{Pa} \text { zero-peak (broadband) } \\
\mathrm{dB} \text { re } 1 \mu \mathrm{Pa} \text { peak-peak (broadband) } \\
\mathrm{dB} \text { re } 1 \mu \mathrm{Pa} \text { rms (over } 90 \% \text { pulse duration) } \\
\mathrm{dB} \text { re } 1 \mu \mathrm{Pa}^{2} \text { s per pulse (SEL) } \\
\text { Energy (joules } \mathrm{m}^{-2} \text { per airgun pulse) } \\
\text { Signal duration (define how measured) }\end{array}$ \\
\hline Map showing modelled sound levels & $\begin{array}{l}\text { Rise time, crest factor, rms, peak-peak and SEL for all areas where } \\
\text { levels are likely to affect marine mammals }\end{array}$ \\
\hline Details of noise propagation model & Including assumptions about sound speed profiles \\
\hline \multicolumn{2}{|l|}{ Specifications of PAM system } \\
\hline Number of hydrophones & Number of elements and spacing \\
\hline Threshold of recording system & $\begin{array}{l}\text { Frequency response of all hydrophones, geophones, accelerometers, } \\
\text { amplifiers, etc. }\end{array}$ \\
\hline Sample rate & Sample rate to be used for acquiring acoustic data \\
\hline Positioning of hydrophones & Where will these be positioned in relation to airguns? \\
\hline Duty cycle & Details of recording duty cycle, if used \\
\hline PAM software to be used & Several may be used concurrently \\
\hline Species covered & Species that can be reliably detected by the system \\
\hline Estimated range accuracy & The likely accuracy of any range determination (m) \\
\hline
\end{tabular}

Brazil, and Colombia have specific guidelines for EIAs for oil and gas activities (Reyes et al. 2016).

EIAs and final reports should be available to the general public and not considered classified (e.g. Colombia). This information could be used as a monitoring database and management tool to increase our understanding and knowledge on the subject, as well as to determine research questions that require further investigation. Thus, oil companies can help bridge these theoretical and practical gaps to minimize impacts, for example, by establishing the maximum sound level used in seismic operations in relation to the wide range of species' tolerance and resistance.

Seismic surveying operations are also performed at night to reduce costs, increasing the risk of harm to marine creatures. Even with night-vision binoculars, 
the efficiency of a marine mammal observer (MMO) to sight wildlife is reduced. Additional precautions should be included for nighttime activities. In places like the Gulf of Mexico, Brazil, and New Zealand, seismic surveying at night is allowed.

The long- and medium-term sub-lethal effects of seismic surveying on the survival of individuals, their fitness, and the potential effects on population dynamics require further investigation; this is the responsibility of governments, universities, institutions, non-governmental organizations (NGOs), and industry. It is not enough for environmental control entities to conform to the minimum standards without knowing what is affected and to what extent. There is evidence arguing that anthropogenic and economic development produces changes in marine systems (e.g. soft bottoms) that can disturb species. However, progress does not justify ignoring the magnitude of the impacts and mechanisms of compensation for biodiversity loss in the pelagic and seabed systems; this is unacceptable.

Life history, life cycle, population size, structure, and dynamics, as well as the different factors that can alter organisms and the viability of a given population must be established a priori if the objective is to prevent and minimize any adverse effects on the species in question (Allen 2015). Furthermore, to develop preventive measures, it should be incumbent on the survey proponents to develop models of sound propagation pertinent to the seismic survey source, the proposed survey location, and environmental features in the area (e.g. seabed types), which are critical to sound transmission to estimate ranges for different impacts. Such modeling will determine the distance from the source (airguns) required by marine organisms to prevent the risk of damage to tissues or alterations in their behavior. According to British standards (JNCC 2017), this space is a $500 \mathrm{~m}$ radius (horizontal effect), although the size of the mitigation zone can be adjusted if necessary. An alternative approach is to define the exclusion zone on a survey-specific basis. This could be determined by calculating the radius of received level (SPL) around the sound source; for Californian guidelines, the received level is $180 \mathrm{~dB}$ re $1 \mu \mathrm{Pa}$ rms (HESS Team 1999). The same SPL value is taken by New Zealand at a $1 \mathrm{~km}$ radius, requesting that the mitigation zone of $1.5 \mathrm{~km}$ must be monitored at all times; during seismic production the zone reduces to $1 \mathrm{~km}$ except when groups including calves are reported, in which case the $1.5 \mathrm{~km}$ radius remains (New Zealand Department of Conservation 2013). Although these mitigation measures have been evaluated and criticized
(Compton et al. 2008, Wright \& Cosentino 2015, Forney et al. 2017), more studies should be conducted to assess the effectiveness of these measures. A sound propagation model would increase the efficacy of mitigation measures and requirements, particularly in Latin America, where the marine regime differs radically between Caribbean and Pacific, and tropical and subtropical waters. Only Brazil and Colombia include the requirement of sound propagation modeling in their EIAs (Reyes et al. 2016). These models would also assist MMOs who must continuously monitor activity in the mitigation zone throughout the seismic exercise.

\section{Mitigation}

The main measures employed globally to prevent the potential harmful effects of marine seismic surveying are (1) the presence of MMOs in the field; (2) a gradual increase of signal intensity at the beginning of the procedure ('soft-start' or 'ramp-up'); (3) implementation of wildlife exclusion zones (EZs) within which air guns can be shut down or their use delayed if any marine mammal is detected; (4) regulation of nighttime seismic survey activity; (5) monitoring submerged cetacean species using passive acoustic monitoring (PAM); and (6) determining critical habitats/seasons for organisms where seismic exploration should not be allowed (Table 4). Further study is required to validate the effectiveness of these measures to minimize the harmful effects of seismic surveys.

Mitigation measures should be stricter, forcing boats to use PAM and, potentially, unmanned aerial vehicles (UAVs), to verify the presence of near-surface fish shoals within the mitigation zone. We propose other mitigation provisions that could be implemented during seismic surveying; however, many of them require ongoing scientific investigation (Table 4). Species, areas of ecological importance, qualified observers, and seismic protocols need to be integrated to guarantee a minimal impact on the marine fauna.

PAM and MMO deployment would support the monitoring of many species of fish, turtle, shark, cetacean, and other species of concern. In some parts of the world, an MMO must notify the ship's captain or a member of the seismic crew upon sighting wildlife in the mitigation zone to stop the airguns firing. However, this requirement is not always fulfilled. An observer's decision to shut down and restart a seismic exercise can cause significant eco- 
Table 4. Mitigation provisions to be implemented during seismic surveying in Latin American waters, based on New Zealand's Code of Conduct and UK regulation (New Zealand Department of Conservation 2013, JNCC 2017). If a license is granted, several key mitigation provisions should be implemented during the course of the seismic survey. Note: it is highly recommended that shooting only occurs during daylight as there are no explicit mitigation provisions when shooting at night. PAM: passive acoustic monitoring; MMOs: marine mammal observers

\begin{tabular}{|c|c|}
\hline Mitigation provision & Notes \\
\hline Higher mitigation standards for certain species & $\begin{array}{l}\text { Species of concern (IUCN status, included in management plans) to be } \\
\text { given extra consideration }{ }^{\text {; }} \text {, these should include those species particu- } \\
\text { larly sensitive to acoustic disturbance (e.g. beaked whales), threatened } \\
\text { species (e.g. Franciscana, Chilean dolphin) and those species that } \\
\text { breed seasonally in certain areas (e.g. southern right whales) }\end{array}$ \\
\hline Higher mitigation standards for larger arrays & $\begin{array}{l}\text { Larger mitigation zones for larger arrays }{ }^{\mathrm{a}} \text {. We recommend modeling of } \\
\text { sound propagation for each survey, the acoustic thresholds that would } \\
\text { (or may?) be used to determine the extent of the mitigation zone could } \\
\text { be review at NMFS (2016) }\end{array}$ \\
\hline $\begin{array}{l}\text { Adaptive management procedures required in } \\
\text { certain areas }\end{array}$ & $\begin{array}{l}\text { Additional mitigative measures for Areas of Ecological Importance (e.g } \\
\text { extending radius of mitigation zone as a result of modelling predicted } \\
\text { sound levels and potential impacts on species present) }{ }^{\mathrm{a}} \text { pre-shooting } \\
\text { search extended in waters }>200 \mathrm{~m} \text { deep (to at least } 60 \mathrm{~min} \text { ) }\end{array}$ \\
\hline $\begin{array}{l}\text { Adaptive management procedures required for } \\
\text { certain behavioral states }\end{array}$ & $\begin{array}{l}\text { Avoid surveys where species of concern are likely to be feeding, } \\
\text { breeding, calving or pupping }{ }^{\text {a }}\end{array}$ \\
\hline Mitigation zones vary by species & $\begin{array}{l}\text { At least } 500 \mathrm{~m}_{\text {; }} \text { more stringent for species of concern (at least } 1000 \mathrm{~m} \text { or } \\
1500 \mathrm{~m} \text { for groups with calves) }{ }^{\mathrm{a}}\end{array}$ \\
\hline Impact assessment reporting requirements & Marine mammal impact assessment \\
\hline $\begin{array}{l}\text { MMO required when source in water during } \\
\text { daylight }\end{array}$ & From 2 qualified MMOs on board ${ }^{\mathrm{b}}$ \\
\hline PAM operator required when source in water & From 2 PAM operators on board \\
\hline Provisions for failure of PAM system & Only $2 \mathrm{~h}$ possible without PAM \\
\hline Pre-shooting search & $\begin{array}{l}\text { Visual assessment to verify no marine organisms within } 500 \mathrm{~m} \text { of the } \\
\text { center of the airgun array. This should be done at least } 30 \text { min before } \\
\text { shooting }\end{array}$ \\
\hline Soft-starts required & Over $20-40 \mathrm{~min}$ \\
\hline Soft-starts required after break in firing & Only if $>5 \mathrm{~min}$ \\
\hline Shut-down between lines & Soft-start required if transit time $>20 \mathrm{~min}$ \\
\hline $\begin{array}{l}\text { Delayed starts in response to detection of marine } \\
\text { mammal }\end{array}$ & $\begin{array}{l}30 \text { min delay when within } 500 \mathrm{~m} \text { (varies according to species of con- } \\
\text { cern, e.g. at least } 1000 \mathrm{~m} \text { or } 1500 \mathrm{~m} \text { for groups with calves); monitored } \\
\text { for } \geq 30 \mathrm{~min} \text { prior to survey }\end{array}$ \\
\hline $\begin{array}{l}\text { Shut-downs in response to detection of marine } \\
\text { mammal }\end{array}$ & When within 500-1500 m (varies according to species of concern) \\
\hline Consideration of multiple surveys/arrays & Mitigation applied according to combined capacities of arrays \\
\hline $\begin{array}{l}\text { Other alternative approaches that could be taken } \\
\text { based on local environmental agencies knowledg }\end{array}$ & \\
\hline
\end{tabular}

nomic losses. Some guidelines indicate that seismic survey operations may recommence after $30 \mathrm{~min}$ once the animals have moved outside the mitigation zone (see Weir \& Dolman 2007), but most guidelines would require another soft start before reaching operational levels. The UK's guidelines also suggest that start-up activities take place using a soft-start procedure (JNCC 2017), which delays the retrieval of valid seismic data under normal operating conditions.
According to an anonymous reliable source, because of the high functioning costs involved, the crew or captain may not always execute these power-down measures in undeveloped countries. To adequately detect wildlife, 2 trained observers are required (e.g. MMOs for cetaceans only) to scan the mitigation zone and identify the presence of marine mammals in order to mitigate surveying activities. The impact of seismic surveys on trophic levels and entire eco- 
systems (soft-bottom invertebrates, epipelagic zone fish schools, and plankton) should also be researched (e.g. design of new underwater monitoring devices).

Some guidelines stipulate that airguns should be completely powered down during line changes or when outside of the seismic prospecting area (Weir \& Dolman 2007). However, if the guns stop firing and a group of animals enter the mitigation zone without being detected by PAM/MMOs, they may be subjected to harm if the soft start is not used to avoid high doses. Another alternative often used is to power down but keep the smallest gun in the array firing (the mitigation gun) to alert marine life to the presence of a potentially noisy sound source. Before recommencing the survey, a soft-start procedure should be undertaken with pre-shooting search by MMOs/PAM.

Areas most vulnerable to seismic prospecting should be avoided at critical times, particularly key areas used by marine fauna for life processes (Jiménez-Pinedo et al. 2014, Allen 2015). These areas include breeding, calving, and feeding areas, as well as migration corridors, diversity hotspots, and main habitats for some species of commercial interest. As in many parts of the world, there is an information gap in Latin America regarding the delineation of the key marine habitats available for exploration. Seismic operations further increase the pressures on species that are threatened, vulnerable, or endangered (Naranjo \& Amaya 2009). Environmental authorities need to map key habitats and recognize listed species before allocating blocks for seismic exploration. This mapping exercise will need to be routinely reviewed, as habitat use is often a dynamic process. In the case of fish and invertebrates, ecosystems that should be avoided are cold-water coral reefs (mesophotic 50 to $150 \mathrm{~m}$ ), fishing grounds, shallow-water seamounts (summit between 200 and $1000 \mathrm{~m}$ ), and current convergence zones, among others-not only for their ecological prominence, but also their socioeconomic importance to fishing communities (Hirst \& Rodhouse 2000). Seasonality must also be taken into account when granting licenses for seismic operations within the blocks, as many of the species' life processes are seasonal (Weir \& Dolman 2007, Allen 2015).

Among the countries that exclude seismic operations from some determined areas are the United States and Australia. Other countries including the UK, Brazil, and New Zealand restrict the use of seismic surveying in certain areas for specific periods because of the requirements of local marine populations. In Canada, seismic operations are allowed in sensitive areas, but it is recommended they be avoided. In the Gulf of Mexico, seismic surveying operations are fully allowed, regardless of the area's vulnerability (Weir \& Dolman 2007). Area or seasonal restrictions are more likely to be imposed by the local authority/government when the seismic permit is granted, so it is much more likely that any exclusion zone will be considered on a case-by-case basis. However, strict application of the guidelines should be a commitment from the companies prior to being granted a license by the government. The idea of these measures is to maintain the quality of habitat and avoid degrading the system's ecological value. While human activity leaves a mark, it should be minimal. Perhaps the design of a new method to carry out seismic operations (e.g. devices that emit seismic waves closer to the seabed, so that they do not affect the water column) can be a new alternative to lessen the impact of the conventional procedure. The development of marine vibroseis seismic sources offers an alternative to traditional marine seismic airguns (Racca \& Austin 2016). This source produces the same energy or a lower peak intensity than an airgun array, but over a longer time frame (longer pulse length), making it a non-impulsive signal. Marine vibroseis may produce behavioral responses in marine fauna at a given range without causing damage, thus minimizing the potential for ecological-scale impacts. However, these sources will not be developed unless management agencies insist on their use or there is some advantage to industry (e.g. a financial benefit). The proposed standard mitigation measures should be adopted by Latin American countries (nearly 20); however, it will be a challenge for different governments to implement them, given the different laws, regulatory and licensing regimes, as well as particular economic, environmental, and scientific priorities that exist among countries.

\section{CONCLUSIONS}

There is scientific evidence suggesting that the intense impulsive signals produced during oil or gas seismic surveys cause sub-lethal effects on fish (in vitro experimental data), as well as cetaceans (in situ data). A flight response, which is a change in orientation or swim speed, could be the first observable effect of the disturbance on fish and cetaceans. Interference with the communication process has been documented in cetaceans, as well as temporal hearing loss in fish. However, further research is needed to fully understand the processes and the interactions of seismic activities with pelagic and benthic organisms. 
One of the tools needed to implement precautionary impact mitigation measures is sound propagation models specific to seismic survey source, survey location, and environmental features in the area. PAM from autonomous underwater vehicles (AUVs) could be integrated with measures of the sound from the seismic surveys, allowing truthing of sound propagation models (this is required in both pressure and particle motion). These data are critical to understand sound transmission, estimate the ranges for different impact types in the tropics (e.g. Caribbean, Pacific, and Atlantic), and characterize the sound levels that potentially affect species according to their tolerance thresholds. The models would help prevent the risk of tissue damage or behavior alterations in marine organisms by determining the distance required to avoid the disturbance source (airguns).

Besides relevant regulations, continued monitoring and further investigation in the tropics must be conducted to evaluate the impact on marine organisms and enable the design of new strategies that diminish its effect. This seismic information must be provided by oil companies to both environmental agencies and the public to promote adaptive management and improve legislation. New methods are required to replace and improve traditional seismic operations to maintain the quality of local habitats and preserve the system's ecological function.

Acknowledgements. We thank the Pontificia Universidad Javeriana for the financial support and the anonymous reviewers for their valuable comments to improve the manuscript, as well as the Ministerio de Ambiente y Desarrollo Sostenible de la República de Colombia for providing relevant information. We also thank Gypsy Espanol for the English translation and proof reading an earlier version of this paper (Traducciones TyT).

\section{LITERATURE CITED}

Aalbers SA, Drawbridge MA (2008) White seabass spawning behavior and sound production. Trans Am Fish Soc 137:542-550

Aguilera-Hellweg M, McCarthy M (2002) Killing whales with sound. Discover Magazine, April 2002 Issue. http:// discovermagazine.com/authors/susan-mccarthy

Allen A (2015) Cetacean conservation in the age of oil and gas: minimizing acoustic disturbance to the northern bottlenose whale (Hyperoodon ampullatus) through spatiotemporal mitigation. Dalhousie University, Halifax. http: //dalspace.library.dal.ca:8080/xmlui/handle/10222/56363 (accessed 27 July 2014)

Amorim MCP, Neves ASM (2007) Acoustic signalling during courtship in the painted goby, Pomatoschistus pictus. J Mar Biol Assoc UK 87:1017-1023

Amundsen L, Westerdahl H, Thompson M (2016) Apparatus for marine seismic survey. Google Patents. https://www.
google.tl/patents/US9389323

André M, Solé M, Lenoir M, Durfort M and others (2011) Low-frequency sounds induce acoustic trauma in cephalopods. Front Ecol Environ 9:489-493

Andriguetto-Filho JM, Ostrensky A, Pie MR, Silva UA, Boeger WA (2005) Evaluating the impact of seismic prospecting on artisanal shrimp fisheries. Cont Shelf Res 25:1720-1727

Australian Government (2008) EPBC Act Policy Statement 2.1-Interaction between offshore seismic exploration and whales. Australian Government, Department of the Environment, Water, Heritage and the Arts, Canberra

Bain DE, Williams R (2006) Long-range effects of airgun noise on marine mammals: responses as a function of received sound level and distance. Int Whal Comm Sci Comm Doc SC/58/E35. International Whaling Commission, Cambridge

Blackwell SB, Nations CS, McDonald TL, Thode AM and others (2015) Effects of airgun sounds on bowhead whale calling rates: evidence for two behavioral thresholds. PLOS ONE 10:e0125720

Blaxter JHS (1969) Swimming speeds of fish. FAO Fish Rep 62:69-100

Boeger WA, Pie MR, Ostrensky A, Cardoso MF (2006) The effect of exposure to seismic prospecting on coral reef fishes. Braz J Oceanogr 54:235-239

Boudreau M, Courtenay SC, Lee K (2009) Proceedings of a workshop held 23 January at the Gulf Fisheries Center: potential impacts of seismic energy on snow crab: an update to the September review. Can Tech Rep Fish Aquat Sci 2836:7-31

* Brkic I, Jambrosic K, Ivancevic B (2004) Perception of sound by animals in the ocean. In: Kos T (ed) Electronics in marine: proceedings of Elmar 2004, $46^{\text {th }}$ International Symposium. ELMAR, Zadar, p 258-264 http://ieeexplore. ieee.org/stamp/stamp.jsp?tp=\&arnumber $=1356384$

Canada National Energy Board (2008) Statement of Canadian practice with respect to the mitigation of seismic sound in the marine environment. Department of Fisheries and Oceans Canada, Ottawa

Carlson TJ (2012) Barotrauma in fish and barotrauma metrics. In: Popper AN, Hawkins AD (eds) The effects of noise on aquatic life. Advances in experimental medicine and biology, Vol 730. Springer, New York, NY, p 229-233

Castellote M, Clark CW, Lammers MO (2012) Acoustic and behavioural changes by fin whales (Balaenoptera physalus) in response to shipping and airgun noise. Biol Conserv 147:115-122

Cerchio S, Strindberg S, Collins T, Bennett C, Rosenbaum H (2014) Seismic surveys negatively affect humpback whale singing activity off northern Angola. PLOS ONE 9: e86464

Clark CW, Gagnon GC (2006) Considering the temporal and spatial scales of noise exposures from seismic surveys on baleen whales. Int Whal Comm Sci Comm Doc SC/ 58/E9. International Whaling Commission, Cambridge

Clark CW, Ellison WT, Southall BL, Hatch L, Van Parijs SM, Frankel A, Ponirakis D (2009) Acoustic masking in marine ecosystems: intuitions, analysis, and implication. Mar Ecol Prog Ser 395:201-222

Compton R, Goodwin L, Handy R, Abbott V (2008) A critical examination of worldwide guidelines for minimising the disturbance to marine mammals during seismic surveys. Mar Policy 32:255-262

Cott PA, Popper AN, Mann DA, Jorgenson J, Hanna BW 
(2012) Impacts of river-based air gun seismic activity on northern fish. Adv Exp Med Biol 730:367-369

Courtenay SC, Boudreau M, Lee K (eds) (2009) Potential impacts of seismic energy on snow crab: an update to the September 2004 peer review. Environmental Studies Research Funds Report No. 178. Fisheries and Oceans Canada, Moncton

Cox TM, Ragen TJ, Read AJ, Vos E and others (2006) Understanding the impacts of anthropogenic sound on beaked whales. J Cetacean Res Manag 7:177-187

Dennison S, Moore MJ, Fahlman A, Moore K and others (2012) Bubbles in live-stranded dolphins. Proc R Soc B 279:1396-1404

Di Iorio L, Clark CW (2010) Exposure to seismic survey alters blue whale acoustic communication. Biol Lett 6: 51-54

Dolman SJ, Reid RJ, Barley JP, Deaville R and others (2008) A preliminary note on the unprecedented strandings of 45 deep-diving odontocetes along the UK and Irish coast between January and April 2008. Int Whal Comm Sci Comm Doc SC/60/E5. International Whaling Commission, Cambridge

Dunlop R, Noad MJ, McCauley RD, Kniest E, Paton D, Cato $\mathrm{D}$ (2015) The behavioural response of humpback whales to a 20 cubic inch air gun. Aquat Mamm 41:412-433

Ebuna DR, Mitchell T, Hogan P, Nishenko S, Greene H (2013) High resolution offshore 3D seismic geophysical studies of infrastructure geohazards. In: Smith BD (ed) Symposium on the application of geophysics to engineering and environmental problems (SAGEEP). Environmental and Engineering Geophysical Society, Denver, CO, p 311-320

Engås A, Løkkeborg S (2002) Effects of seismic shooting and vessel-generated noise on fish behaviour and catch rates. Bioacoustics 12:313-316

Engås A, Løkkeborg S, Ona E, Soldal AV (1996) Effects of seismic shooting on local abundance and catch rates of cod (Gadus morhua) and haddock (Melanogrammus aeglefinus). Can J Fish Aquat Sci 53:2238-2249

Engel MH, Marcondes MCC, Martins CCA, Luna FO, Lima RP, Campos A (2004) Are seismic surveys responsible for cetacean strandings? An unusual mortality of adult humpback whales in Abrolhos Bank, northeastern coast of Brazil. Int Whal Comm Sci Comm Doc SC/56/E28. International Whaling Commission, Cambridge

Erbe C (2011) Underwater acoustics: noise and the effects on marine mammals. A pocket handbook, $3^{\text {rd }}$ edn. JASCO Applied Sciences, Victoria

Evans DL, England GR (2001) Joint interim report: Bahamas marine mammal stranding event of 15-16 March 2000. US Department of Commerce and Secretary of the Navy, Washington, DC

Evans DH, Claiborne JB, Currie S (2014) Physiology of fishes, $4^{\text {th }}$ edn. CRC Press, Boca Raton, FL

* Fernández A, Edwards J, Rodríguez F, De Los Monteros AE and others (2005) 'Gas and fat embolic syndrome' involving a mass stranding of beaked whales (Family Ziphiidae) exposed to anthropogenic sonar signals. Vet Pathol 42:446-457

Fewtrell JL, McCauley RD (2012) Impact of air gun noise on the behaviour of marine fish and squid. Mar Pollut Bull 64:984-993

Filiciotto F, Vazzana M, Celi M, Maccarrone V and others (2014) Behavioural and biochemical stress responses of Palinurus elephas after exposure to boat noise pollution in tank. Mar Pollut Bull 84:104-114

* Finneran JJ, Carder DA, Ridgway SH (2001) Review of marine mammal temporary threshold shift (TTS) measurements and their application to damage-risk criteria. J Acoust Soc Am 110:2721

Forney KA, Southall BL, Slooten E, Dawson S, Read AJ, Baird RW, Brownell RL Jr (2017) Nowhere to go: noise impact assessments for marine mammal populations with high site fidelity. Endang Species Res 32:391-413

Gannon DP, Barros NB, Nowacek DP, Read AJ, Waples DM, Wells RS (2005) Prey detection by bottlenose dolphins, Tursiops truncatus: an experimental test of the passive listening hypothesis. Anim Behav 69:709-720

Goold JC, Fish PJ (1998) Broadband spectra of seismic survey air-gun emissions, with reference to dolphin auditory thresholds. J Acoust Soc Am 103:2177-2184

Guerra A, González AF, Rocha F (2004) A review of records of giant squid in the Northeastern Atlantic and severe injuries in Architeuthis dux stranded after acoustic exploration. ICES CM 2004/CC:29, ICES, Copenhagen

*Guerra Á, González ÁF, Pascual S, Dawe EG (2011) The giant squid Architeuthis: an emblematic invertebrate that can represent concern for the conservation of marine biodiversity. Biol Conserv 144:1989-1997

* Hassel A, Knutsen T, Dalen J, Skaar K and others (2004) Influence of seismic shooting on the lesser sandeel (Ammodytes marinus). ICES J Mar Sci 61:1165-1173

* Hastings MC, Miksis-Olds J (2012) Shipboard assessment of hearing sensitivity of tropical fishes immediately after exposure to seismic air gun emissions at Scott Reef. Adv Exp Med Biol 730:239-243

Hastings MC, Popper AN (2005) Effects of sound on fish. California Department of Transportation Contract 43A0139, Task Order 1. Jones \& Stokes, Sacramento, CA

* Hawkins A, Rasmussen KJ (1978) The calls of gadoid fish. J Mar Biol Assoc UK 58:891-911

Hawkins AD, Pembroke AE, Popper AN (2015) Information gaps in understanding the effects of noise on fishes and invertebrates. Rev Fish Biol Fish 25:39-64

*Heide-Jørgensen MP, Hansen RG, Westdal K, Reeves RR, Mosbech A (2013) Narwhals and seismic exploration: Is seismic noise increasing the risk of ice entrapments? Biol Conserv 158:50-54

HESS Team (1999) High energy seismic survey review process and interim operational guidelines for marine surveys offshore Southern California. Report prepared by the High Energy Seismic Survey (HESS) team. California State Lands Commission and Minerals Management Service, Camarillo, CA

Hildebrand J (2004) Impacts of anthropogenic sound on cetaceans. Int Whal Comm Sci Comm Doc SC/56/ E13. International Whaling Commission, Cambridge

*Hildebrand J (2009) Anthropogenic and natural sources of ambient noise in the ocean. Mar Ecol Prog Ser 395:5-20

*Hirst AG, Rodhouse PG (2000) Impacts of geophysical seismic surveying on fishing success. Rev Fish Biol Fish 10: 113-118

*Holt DE, Johnston CE (2011) Can you hear the dinner bell? Response of cyprinid fishes to environmental acoustic cues. Anim Behav 82:529-534

*Houser DS, Howard R, Ridgwaya S (2001) Can divinginduced tissue nitrogen supersaturation increase the chance of acoustically driven bubble growth in marine mammals? J Theor Biol 213:183-195

Hovem JM, Tronstad TV, Karlsen HE, Løkkeborg S (2012) 
Modeling propagation of seismic airgun sounds and the effects on fish behavior. IEEE J Oceanic Eng 37:576-588

Jepson PD, Arbelo M, Deaville R, Patterson IA and others (2003) Gas-bubble lesions in stranded cetaceans. Nature 425:575-576

Jiménez-Pinedo C, Domínguez-García C, Pardo MA, Trujillo F, Ávila JM, Palacios DM (2014) Cetacean occurrence in the Tayrona National Park, a marine protected area in the Colombian Caribbean. Lat Am J Aquat Mamm 9:154-159

JNCC (Joint Nature Conservation Committee) (2010) JNCC guidelines for minimising the risk of injury and disturbance to marine mammals from seismic surveys. Joint Nature Conservation Committee, Aberdeen

JNCC (2017) JNCC guidelines for minimising the risk of injury to marine mammals from geophysical surveys. Joint Nature Conservation Committee, Aberdeen

Kaifu K, Segawa S, Tsuchiya K (2007) Behavioral responses to underwater sound in the small benthic octopus Octopus ocellatus. J Mar Acoust Soc Jpn 34:266-273

Kasumyan A (2009) Acoustic signaling in fish. J Ichthyol 49: 963-1020

Kearey P, Brooks M, Hill I (2013) An introduction to geophysical exploration. Blackwell Science, Oxford

Kenyon TN, Ladich F, Yan HY (1998) A comparative study of hearing ability in fishes: the auditory brainstem response approach. J Comp Physiol A 182:307-318

La Bella G, Cannata S, Froglia C, Ratti S, Rivas G (1996) First assessment of effects of air-gun seismic shooting on marine resources in the central Adriatic Sea. SPE Conference Paper SPE-35782-MS. SPE Health, Safety and Environment in Oil and Gas Exploration and Production Conference. Society of Petroleum Engineers, New Orleans, LA, p 227-238

Ladich F, Fay RR (2013) Auditory evoked potential audiometry in fish. Rev Fish Biol Fish 23:317-364

Liberman MC (2016) Noise-induced hearing loss: permanent vs. temporary threshold shifts and the effects of hair-cell vs. neuronal degeneration. In: Popper AN, Hawkins AD (eds) The effects of noise on aquatic life II. Advances in experimental medicine and biology, Vol 875. Springer, New York, NY, p 1-8

Ljungblad DK, Würsig B, Swartz SL, Keene JM (1988) Observations on the behavioral responses of bowhead whales (Balaena mysticetus) to active geophysical vessels in the Alaskan Beaufort Sea. Arctic 41:183-194

Løkkeborg S, Soldal AV (1993) The influence of seismic exploration with air guns on cod (Gadus morhua) behaviour and catch rates. ICES Mar Sci Symp 196:62-67

Løkkeborg S, Ona E, Soldal A, Salthaug A (2012a) Effects of sounds from seismic airguns on fish behavior and catch rates. In: Popper AN, Hawkins AD (eds) The effects of noise on aquatic life. Advances in experimental medicine and biology, Vol 730. Springer, New York, NY, p 415-419

* Løkkeborg S, Ona E, Vold A, Salthaug A (2012b) Sounds from seismic air guns: gear- and species-specific effects on catch rates and fish distribution. Can J Fish Aquat Sci 69:1278-1291

Lucke K, Siebert U, Lepper PA, Blanchet MA (2009) Temporary shift in masked hearing thresholds in a harbor porpoise (Phocoena phocoena) after exposure to seismic airgun stimuli. J Acoust Soc Am 125:4060

Malme CI, Miles PR, Clark CW, Tyack PL, Bird JE (1984) Investigations of the potential effects of underwater noise from petroleum-industry activities on migrating gray whale behavior. Phase 2: January 1984 migration. Report No. 5586. Bolt, Beranek and Newman, Cambridge, MA

Malme CI, Würsig B, Bird JE, Tyack PL (1986) Behavioral responses of gray whales to industrial noise: feeding observations and predictive modeling. Report No. 393. BBN Labs, Cambridge, MA

*Mann DA, Higgs DM, Tavolga WN, Souza MJ, Popper AN (2001) Ultrasound detection by clupeiform fishes. J Acoust Soc Am 109:3048-3054

McCauley RD, Kent CS (2012) A lack of correlation between air gun signal pressure waveforms and fish hearing damage. Adv Exp Med Biol 730:245-250

*McCauley RD, Jenner MN, Jenner C, McCabe KA, Murdoch $\mathrm{J}$ (1998) The response of humpback whales (Megaptera novaeangliae) to offshore seismic survey noise: preliminary results of observations about a working seismic vessel and experimental exposures. APPEA J 38:692-707

McCauley RD, Fewtrell J, Duncan AJ, Jenner C and others (2000) Marine seismic surveys: a study of environmental implications. APPEA J 40:692-708

* McCauley RD, Fewtrell J, Popper AN (2003) High intensity anthropogenic sound damages fish ears. J Acoust Soc Am 113:638-642

McCauley RD, Day R, Swadling K, Fitzgibbon Q, Watson R, Semmens J (2017) Widely used marine seismic survey air gun operations negatively impact zooplankton. Nat Ecol Evol 1:0195

Miller I, Cripps E (2013) Three dimensional marine seismic survey has no measurable effect on species richness or abundance of a coral reef associated fish community. Mar Pollut Bull 77:63-70

Miller PJO, Tyack PL, Biassoni N, Johnson MP (2005) Shortterm effects of suction cup tagging on the deep-diving behaviour of sperm whales. Poster presentation, $2^{\text {nd }}$ international bio-logging science symposium, 13-16 June 2005, St. Andrews

Miller PJ, Johnson MP, Madsen PT, Biassoni N, Quero M, Tyack PL (2009) Using at-sea experiments to study the effects of airguns on the foraging behavior of sperm whales in the Gulf of Mexico. Deep Sea Res I 56: 1168-1181

Minerals Management Service Gulf of Mexico OCS (2016) Current seismic surveys mitigation measures in the GOM. US Department of the Interior, Minerals Management Service (MMS), Gulf of Mexico (GOM) OCS Region. NOAA Fisheries Office of Protected Resources, Silver Spring, MD

Naranjo L, Amaya J (2009) Plan nacional de las especies migratorias: diagnóstico e identificación de acciones para la conservación y el manejo sostenible de las especies migratorias de la biodiversidad en Colombia. República de Colombia Ministerio de Ambiente, Vivienda y desarrollo Territorial. WWF Colombia, Bogotá

NMFS (National Marine Fisheries Service) (2016) Technical guidance for assessing the effects of anthropogenic sound on marine mammal hearing: underwater acoustic thresholds for onset of permanent and temporary threshold shifts. NOAA Tech Memo NMFS-OPR-55. US Department of Commerce, Silver Spring, MD

*Neo YY, Ufkes E, Kastelein RA, Winter HV, ten Cate C, Slabbekoorn H (2015) Impulsive sounds change European seabass swimming patterns: influence of pulse repetition interval. Mar Pollut Bull 97:111-117

New Zealand Department of Conservation (2013) Code of 
conduct for minimising acoustic disturbance to marine mammals from seismic survey operations. Department of Conservation, Wellington. www.doc.govt.nz/Documents/ conservation/native-animals/marine-mammals/seismicsurvey-code-of-conduct.pdf

Nieukirk SL, Mellinger DK, Moore SE, Klinck K, Dziak RP, Goslin J (2012) Sounds from airguns and fin whales recorded in the mid-Atlantic Ocean, 1999-2009. J Acoust Soc Am 131:1102

Nowacek DP, Thorne LH, Johnston DW, Tyack PL (2007) Responses of cetaceans to anthropogenic noise. Mammal Rev 37:81-115

Parks SE, Clark CW, Tyack PL (2007) Short- and long-term changes in right whale calling behaviour: the potential effects of noise on acoustic communication. J Acoust Soc Am 122:3725-3731

* Parks SE, Johnson M, Nowacek D, Tyack PL (2011) Individual right whales call louder in increased environmental noise. Biol Lett 7:33-35

Parry GD, Gason A (2006) The effect of seismic surveys on catch rates of rock lobsters in western Victoria, Australia. Fish Res 79:272-284

* Pearson WH, Skalski JR, Malme CI (1992) Effects of sounds from a geophysical survey device on behaviour of captive rockfish (Sebates spp.). Can J Fish Aquat Sci 49: 1343-1356

* Peña H, Handegard NO, Ona E (2013) Feeding herring schools do not react to seismic air gun surveys. ICES J Mar Sci 70:1174-1180

Persen LN (2013) Rock dynamics and geophysical exploration. Elsevier, Amsterdam

Pirotta E, Brookes KL, Graham IM, Thompson PM (2014) Variation in harbour porpoise activity in response to seismic survey noise. Biol Lett 10:20131090

Popper AN (2003) Effects of anthropogenic sounds on fishes. Fisheries (Bethesda, Md) 28:24-31

Popper AN, Hastings M (2009) The effects of anthropogenic sources of sound on fishes. J Fish Biol 75:455-489

Popper AN, Smith ME, Cott PA, Hanna BW, MacGillivray AO, Austin ME, Mann DA (2005) Effects of exposure to seismic airgun use on hearing of three fish species. J Acoust Soc Am 117:3958-3971

Popper AN, Hawkins AD, Fay RR, Mann DA and others (2014) ASA S3/SC1.4 TR-2014. Sound exposure guidelines for fishes and sea turtles: a technical report prepared by ANSI Accredited Standards Committee S3/SC1 and Registered with ANSI. Springer, New York, NY

Popper AN, Carlson TJ, Gross JA, Hawkins AD, Zeddies D, Powell L, Young J (2016) Effects of seismic air guns on pallid sturgeon and paddlefish. Adv Exp Med Biol 875: 871-878

Racca R, Austin M (2016) Use of preoperation acoustic modeling combined with real-time sound level monitoring to mitigate behavioral effects of seismic surveys. In: Popper AN, Hawkins AD (eds) The effects of noise on aquatic life II. Advances in experimental medicine and biology, Vol 875. Springer, New York, NY, p 885-893

* Radford AN, Lèbre L, Lecaillon G, Nedelec SL, Simpson SD (2016) Repeated exposure reduces the response to impulsive noise in European seabass. Glob Change Biol 22:3349-3360

Ramos S, Perez Y, Alvarez P, Vidal D (2012) Potential benefits of 3D-3C seismic data for the reservoir characterization of an extra-heavy oil reservoir and its seismic survey design. In: SEG technical program expanded abstracts
2012. Society of Exploration Geophysicists, Tulsa, OK. http://library.seg.org/doi/abs/10.1190/segam2012-1208.1

Reyes MV, Iñíguez MA, Dolman SJ (2016) Review of legislation applied to seismic surveys to mitigate effects on marine mammals in Latin America. Proc Meet Acoust 27: 032002 doi:10.1121/2.0000285

* Richardson WJ, Würsig B, Greene CR Jr (1986) Reactions of bowhead whales, Balaena mysticetus, to seismic exploration in the Canadian Beaufort Sea. J Acoust Soc Am 79: 1117-1128

Richardson WJ, Greene CR Jr, Malme CI, Thomson DH (1995) Marine mammals and noise. Academic Press, San Diego, CA

Richardson WJ, Miller GW, Greene CR Jr (1999) Displacement of migrating bowhead whales by sounds from seismic surveys in shallow waters of the Beaufort Sea. J Acoust Soc Am 106:2281

Komano T, Keogh M, Kelly C, Feng P and others (2004) Anthropogenic sound and marine mammal health: measures of the nervous and immune systems before and after intense sound exposure. Can J Fish Aquat Sci 61: 1124-1134

Santulli A, Modica A, Messina C, Ceffa L and others (1999) Biochemical responses of European Sea Bass (Dicentrarchus labrax L.) to the stress induced by off shore experimental seismic prospecting. Mar Pollut Bull 38: 1105-1114

Scheifele PM, Andrew S, Cooper RA, Darre M, Musiek FE, Max L (2005) Indication of a Lombard vocal response in the St. Lawrence River beluga. J Acoust Soc Am 117: 1486-1492

* Schlundt CE, Finneran JJ, Carder DA, Ridgway SH (2000) Temporary shift in masked hearing thresholds of bottlenose dolphins, Tursiops truncatus, and white whales, Delphinapterus leucas, after exposure to intense tones. J Acoust Soc Am 107:3496-3508

Serway R, Jewett J (2013) Physics for scientists and engineers with modern physics, 9th edn. Brooks/Cole Cengage Learning, Boston, MA

Slotte A, Hansen K, Dalen J, One E (2004) Acoustic mapping of pelagic fish distribution and abundance in relation to a seismic shooting area off the Norwegian west coast. Fish Res 67:143-150

Smith M, Kane A, Hastings M, Popper A (2003) Physiological effects of noise on fishes. In: De Jong RG, Houtgast T, Franssen EAM, Hofmab WF (eds) Proceedings of the $8^{\text {th }}$ international congress on noise as a public health problem. Rotterdam, 29 June-3 July 2003. International Commission on Biological Effects of Noise (ICBEN), p 299-305

* Song J, Mann DA, Cott PA, Hanna BW, Popper AN (2008) The inner ears of northern Canadian freshwater fishes following exposure to seismic air gun sounds. J Acoust Soc Am 124:1360-1366

Southall BL, Bowles AE, Ellison WT, Finneran JJ and others (2007) Marine mammal noise exposure criteria: initial scientific recommendations. Aquat Mamm 33:411-414

Speight JG (2015) Occurrence and formation of crude oil and natural gas. In: Handbook of offshore oil and gas operations. Gulf Professional Publishing, Waltham, MA, p 1-43

Stephenson JR, Gingerich AJ, Brown RS, Pflugrath BD and others (2010) Assessing barotrauma in neutrally and negatively buoyant juvenile salmonids exposed to simulated hydroturbine passage using a mobile aquatic barotrauma laboratory. Fish Res 106:271-278 
Stone CJ, Tasker ML (2006) The effects of seismic airguns on cetaceans in UK waters. J Cetacean Res Manag 8:255

Supin A, Popov V, Nechaev D, Sysueva E, Rozhnov V (2016) Is sound exposure level a convenient metric to characterize fatiguing sounds? A study in beluga whales. Adv Exp Med Biol 875:1123-1129

Sverdrup A, Kjellsby E, Krüger P, Fløysand R and others (1994) Effects of experimental seismic shock on vasoactivity of arteries, integrity of the vascular endothelium and on primary stress hormones of the Atlantic salmon. J Fish Biol 45:973-995

Taylor B, Barlow J, Pitman R, Ballance L and others (2004) A call for research to assess risk of acoustic impact on beaked whale populations. Int Whal Comm Sci Comm Doc SC/56/E36. International Whaling Commission, Cambridge

Thompson PM, Brookes KL, Graham IM, Barton TR, Needham K, Bradbury G, Merchant ND (2013) Short-term disturbance by a commercial two-dimensional seismic survey does not lead to long-term displacement of harbour porpoises. Proc R Soc B 280:20132001

Thomson R, Sporcic M, Foster S, Haddon M and others (2014) Examining fisheries catches and catch rates for potential effects of Bass Strait seismic surveys. CSIRO and Geoscience Australia, Hobart and Canberra

Truett AA (2007) Ecological risk to cetaceans from anthropogenic ocean sound: characterization analysis using a professional judgment approach to uncertainty. $\mathrm{PhD}$ dissertation, University of Maryland, College Park, MD

Urick RJ (1983) Principles of underwater sound, $3^{\text {rd }}$ edn. McGraw-Hill Book Company, New York, NY

Vaughan TA, Ryan JM, Czaplewski NJ (2013) Mammalogy, $5^{\text {th }}$ edn. Jones and Bartlett Editions, Boston, MA

Editorial responsibility: Paul Sammarco,

Chauvin, Louisiana, USA
Wagner TL, Cooper CD, Gross JA, Coffin AB (2015) The effect of seismic waterguns on the inner ears of round goby. J Gt Lakes Res 41:1191-1196

*Ward D, Morison F, Morrissey E, Jenks K, Watson WH (2011) Evidence that potential fish predators elicit the production of carapace vibrations by the American lobster. J Exp Biol 214:2641-2648

* Wardle C, Carter T, Urquhart G, Johnstone A, Ziolkowski A, Hampson G, Mackie D (2001) Effects of seismic air guns on marine fish. Cont Shelf Res 21:1005-1027

* Wartzok D, Popper AN, Gordon J, Merrill J (2003) Factors affecting the responses of marine mammals to acoustic disturbance. Mar Technol Soc J 37:6-15

*Weilgart LS (2007) The impacts of anthropogenic ocean noise on cetaceans and implications for management. Can J Zool 85:1091-1116

*Weir CR, Dolman SJ (2007) Comparative review of the regional marine mammal mitigation guidelines implemented during industrial seismic surveys, and guidance towards a worldwide standard. J Int Wildl Law Policy 10: $1-27$

Wisniewska DM, Kyhn LA, Tougaard J, Simon M and others (2014) Propagation of airgun pulses in Baffin Bay 2012. Scientific Report No. 109, Danish Centre for Environment and Energy, Aarhus University, Roskilde

Wright AJ, Cosentino AM (2015) JNCC guidelines for minimising the risk of injury and disturbance to marine mammals from seismic surveys: We can do better. Mar Pollut Bull 100:231-239

Xia S, Li Q, Wang X, Sun C and others (2015) Application of 3D fine seismic interpretation technique in Dawangzhuang Area, Bohai Bay Basin, Northeast China. Arab J Geosci 8:87-97

Submitted: April 26, 2017; Accepted: September 7, 2017

Proofs received from author(s): October 30, 2017 